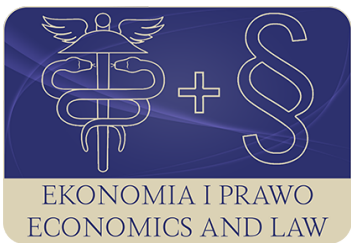

EKONOMIA I PRAWO. ECONOMICS AND LAW

Volume 19, Issue 4, December 2020

p-ISSN 1898-2255, e-ISSN 2392-1625

www.economicsandlaw.pl

ORIGINAL ARTICLE

received 30.03.2019; revised 03.02.2020; accepted 31.12.2020

Citation: Michalczuk, G., \& Konarzewska, U. (2020). Socially responsible investing in the European

Union's capital markets. Ekonomia i Prawo. Economics and Law, 19(4): 757-772. doi:10.12775/EiP.2020.049.

\title{
Socially responsible investing in the European Union's capital markets
}

\author{
GRAŻYNA MICHALCZUK \\ corresponding author \\ University of Bialystok, Faculty of Economics and Finance, Department of Finance, \\ ul. Warszawska 63, 15-062 Bialystok, Poland \\ g.michalczuk@uwb.edu.pl \\ (D) orcid.org/0000-0003-0546-4456
}

URSZULA KONARZEWSKA

University of Bialystok, Faculty of Economics and Finance, Department of Finance, Poland ○.konarzewska@uwb.edu.pl

(iD) orcid.org/0000-0003-1257-3749

\begin{abstract}
Motivation: The growing importance of the corporate social responsibility in the socio-economic sphere means that investors more and more often in their decision-making process include, alongside criteria of the effectiveness of invested capital, factors related to ecology, social development and corporate governance. This leads to diversification of the capital market in which, besides the traditional investing, socially responsible investing is becoming increasingly important.

Aim: The aim of the article is to identify the territorial diversification of socially responsible investments in the European Union's capital markets in terms of value and investment strategies used, as well as to show the reasons for this diversity.

Results: The conducted analysis showed that more and more investors in the European Union base their decisions not only on financial parameters but also on social and environmental factors. However, this market is not homogenous. This applies to both the value and preferences regarding investments strategy. A significant impact on this diversity has the level of implementation of specific legislative solutions creating favourable conditions for the development of socially responsible investing.
\end{abstract}

Keywords: socially responsible investing; socially responsible investing strategies; capital market JEL: G11; M14; O16 


\section{Introduction}

Corporate social responsibility is a concept, which translates into financial markets and decisions making by investors. For many investors, social credibility is the basis for the evaluation of companies. This means that more and more investors, in addition to the criterion of efficiency of capital employed (economic criterion), take into account social, environmental, ethical and corporate governance aspects. This leads to diversification of the capital market in which, besides the traditional investing, socially responsible investing is becoming increasingly important.

In recent years it can be observed an increasing popularity of socially responsible investments. They cease to be perceived as investments in a niche market but are becoming a more and more important instrument of the global financial market. This is indicated by the growth of the value of the global SRI market which was estimated at 22.89 trillion dollars in 2016. However, it is not a unified market, which is reflected in the value of SRI assets in individual regions (table 1 ).

The largest share $(52.6 \%-12$ trillion dollars) in global SRI market has the European market. It is the market, whose dynamic growth has been observed for several years. This is undoubtedly the result of increasing trust in this form of investing among capital market participants. The European market is interesting because, despite the financial crisis, the socially responsible investing in Europe did not fluctuate. Also because, it is the diversified market in terms of the value of SRI investments, rate of their growth, as well as strategies that are being used by investors.

The article intends to fill the gap in the field of socially responsible investing in the context of its diversity, as this aspect still seems under-represented in research. Previous studies undertaken in this field focus primarily on the theoretical aspects of socially responsible investing. In addition, they partially refer to the size of this type of investments in individual countries or groups of countries. However, there is still a lack of studies that would show the territorial diversification in terms of socially responsible investing and attempt to explain the reasons for this diversity.

The aim of the article is to identify the territorial diversification of socially responsible investments in the European Union's capital markets in terms of value and investment strategies used, as well as to show the reasons for this diversity.

The achievement of the set objectives was made possible by answering the following research questions:

- What is the value of socially responsible investments in individual European Union's countries?

- What strategies are used in the process of socially responsible investing in individual European Union's countries? 
- What is the level of implementation of specific legislative solutions creating favourable conditions for the development of this type of investing in selected European Union's countries?

- What activities in the institutional and organizational sphere should be taken for increasing the level of socially responsible investing in the European Union's capital markets?

To achieve the article's purpose a descriptive method which consists of an analysis of literature, and legislative solutions in terms of socially responsible investing as well as the method of desk research based on analysis of data provided by Global Sustainable Investment Alliance (GSIA) and Eurosif were used.

The article is organised as follows: in the first section, the review of the literature related to socially responsible investing was performed. The second section contains a description of the research methodology and sources of information used during the study. The third section presents the results of research concerning the development of socially responsible investing in the European Union's countries and the attempt of explanation of reasons for diversity in this respect. Finally, in the last section, the Authors indicate the most important aspects of the issue being discussed. They also present activities that should be undertaken to ensure the further development of this form of investing.

\section{Literature review}

The increasing social expectations for activities undertaken by companies are reflected in the functioning of financial markets. This is because more and more investors are not purely focused only on maximizing financial benefits from investments but are also interested in investing in a way that will contribute to solving the specific social and environmental problems. (Waring \& Edwards, 2008, p. 135). The effect is the development of a new trend in investing, which is socially responsible investing (SRI), labelled by Sparkes (2002) as a 'global revolution'.

Nielsen (2014, p. 12) defines SRI as long-term investments that are intergenerationally efficient and fair, which creates possibility for a broader analysis of investment opportunities beyond the conventional strategies. Brest \& Born (2013, pp. 22-23), point out that SRI is the type of investments, which are made in order to come up with measurable socio-economic benefits alongside financial gains. Waring et al. (2008, p. 223) also emphasize that socially responsible investing is based on social, environmental and ethical criteria (e.g. labour standards), as well as on financial goals.

According to the definition of the World Economic Forum (2005, p. 7), socially responsible investing is a way of investing that takes into account the impact of investments on wider society and the natural environment, both today and in the future. European Sustainable Investment Forum (Eurosif ${ }^{1}$ ) defines this

${ }^{1}$ Non-profit organisation associating asset managers, pension funds, SRI service providers and other stakeholders including regulators, research providers and NGOs, which is 
form of investing as ethical investments, responsible investments, sustainable investments, and any other investment processes that combine investors' financial objectives with their concerns about environmental, social and governance (ESG) issues (Eurosif, 2014, p. 8). The Forum for Sustainable and Responsible Investment (US SIF) identify socially responsible investing with the strategies which can be applied across asset classes to promote stronger corporate social responsibility, build long-term value for companies and their stakeholders, and foster businesses or introduce products that will yield community and environmental benefits (US SIF Foundation, 2016, p. 12).

When analysing the definitions given, it can be assumed that the essence of socially responsible investing is the selection to investment portfolio those companies that meet the assigned standards of social and environmental responsibility. In this process, companies that are characterized by transparency in the operation, honesty in building their image, and activities undertaken in fields related to sustainable development, environmental protection, human rights protection and diversity, are preferred. This should contribute to encouraging companies to influence of positive social changes, minimize the environmental damages, implement ethical principles, as well as to take on more civic responsibility appearing in dedicating a portion of assets to economic and social development (Fung et al., 2010, p. 1; Iraya \& Musyoki, 2013, p. 82; Kreibohm, 2016, pp. 12-13; Sethi, 2005, p. 101).

Socially responsible investing promotes a broader analysis of investment opportunities going beyond conventional strategies (Urwin \& Woods, 2009, p. 2). However, it is not contrary to the essence of traditional investing based on efficiency criteria. In the process of making an investment decision, financial factors are not the only criteria taken into account by investors. They are supplemented by socio-ethical, ecological and environmental aspects (Kreibohm, 2016, pp. 12-13), which are treated equally with financial factors (Renneboog et al., 2010, p. 395; Schueth, 2003, p. 190; Wagemans et al., 2013, p. 235). This is important because socially responsible investing can translate into positive financial results in the long term for both companies with high ethical and environmental standards and investors taking these standards into account in the decision-making process.

Along with the development of the concept of socially responsible investing, not only new criteria for selection of assets to an investment portfolio but also separate investment strategies have been developed. These strategies provide guidance for managers of socially responsible investment portfolio. In addition, they can be treated as complementary to each other, and used by the same investor at different stages of the investment process.

aimed at promoting the concept of socially responsible investment and supporting the development of the European SRI market (Eurosif, 2018, p. 113). 


\section{Methods}

The research conducted in the article relate to socially responsible investing in the European Union's capital markets. The selection of European Union market is determined by the fact that it is characterized by the largest share in the global market of socially responsible investing and by the largest number of initiatives undertaken to promote this form of investing. Thus, it can be assumed that trends taking place in this market determine the direction of development of socially responsible investing around the world.

To attain the article's purpose, different research tools were used. The article was based on a descriptive method consists of an analysis of literature related to socially responsible investing.

Additionally, the method of desk research consisting in analysing of existing data from various sources was applied. The method of desk research is commonly used in economic sciences. Due to the low costs of obtaining data, it creates the possibility to conduct the analysis based on larger sample sizes, enables comparison of results in the same or similar research fields, and also allows to obtain wide knowledge on a given topic (Bednarowska, 2015, p. 19; Hofferth, 2005, p. 893).

The desk research conducted in this article consisted of analysing the data published by Global Sustainable Investments Alliance and Eurosif. The selected data have been analysed which allowed to group them and conduct the inference process. The result of the desk research was to present trends in development of socially responsible investing in the European Union, as well as to show territorial diversification in terms of value and investment strategies used.

The last part of the research concentrates on finding the reasons for this diversity. For this purpose, the systematization of existing research in this field and the analysis of legislation solutions concerning socially responsible investing in selected European Union countries were performed This allowed the Authors to formulate conclusions and recommendations concerning the socially responsible investing in the European Union's capital markets.

\section{Results}

\subsection{The state and trends in the development of socially responsible investing in the European Union's capital markets}

Socially responsible investing is a concept that is increasingly popular among European Union countries. In 2009, the value of these investments amounted to EUR 4378 billion. While in 2015, it was about EUR 9517 billion, which means an increase of over $200 \%$.

The initiatives undertaken by Eurosif and the European Union play a special role in development of socially responsible investment in Europe. References 
to the concept of socially responsible investing can be found in many European Union's documents, such as Europe 2020: a strategy for smart, sustainable and inclusive growth (European Commission, 2010), as well as European Parliament resolution on corporate social responsibility: accountable, transparent and responsible business behaviour and sustainable growth (2013).

Despite the various initiatives, the SRI market in the European Union is not unified. It is characterized by diversification in terms of the value of socially responsible investments undertaken in individual countries (table 2).

The largest value of the SRI market among European Union countries was characteristic in 2009 for France and Great Britain. They constituted over $63 \%$ of the total EU market. Among these countries, the French market had the largest share in the EU market (42\%). Other markets represented 58\%. The French market also in 2015 had the largest share in the EU market, but it constituted about 33\%. The significant share in the SRI market in the European Union was also characteristic for capital markets in Germany, Great Britain and the Netherlands.

The individual countries are also varied in terms of the rate of growth of socially responsible investments. The greatest growth rate can be observed in Austria. In 2009, the value of the SRI market in this country was estimated at about EUR 2 billion. While in 2015, its value was EUR 52 billion, which means an increase of over $2400 \%$. An increase of over $500 \%$ is characteristic for Poland. The value of socially responsible investments amounted to EUR 1.1 billion in 2009, and EUR 6 billion in 2015. It should also be emphasized that Poland is the only country in Central and Eastern European that are covered by a statistic on socially responsible investing. It is also the country characterized by intense development of these investments.

A characteristic feature of socially responsible investing in the European Union's capital markets is also a diversity in terms of strategies that are being used in this process (chart 1 ).

When analysing data for each year, it can be noticed that investors base their decisions mainly on four strategies i.e. Exclusions, Engagement and Voting, ESG integration, as well as Norms-based screening. However, the changes in preferences for socially responsible investing can be observed. In 2009 and 2011, investors had been deciding in particular on the basis of ESG integration. In 2011, their value amounted to approximately 3173 EUR billion. However, since 2013 the largest share in the market have investments made on the basis of exclusions from investment portfolio those companies whose activity is disadvantageous from an ethical or social point of view. Investments based on this strategy reached EUR 8066 billion in 2017, which means an increase of nearly 600\%.

Engagement and Voting strategy has attracted great interest among investors. During the analysed period, it was the second, in terms of value, strategy used by investors. Except for 2011 and 2015, in which, despite the increase of the value of investments, this strategy was in the third position. 
Also, Norms-based screening had an important role in the investment decision-making process. In 2009-2015, an increase in the value of investments based on this strategy was around $800 \%$. In 2017, the decrease in value of these investments was recorded (to EUR 3078 billion). Within this strategy, the principles of UN Global Compact and OECD Guidelines for Multinational Enterprises were the most commonly used criteria for selection of companies to an investment portfolio.

The great interest in investing on the basis of ESG integration should be also noted. In 2009, approximately EUR 2778 billion were invested using this strategy, while in 2017 this value amounted to over EUR 4161 billion. ESG integration played a particularly important role in 2009 and 2011, in which it was the most commonly used strategy by investors in selected European Union countries.

By contrast, the strategies such as Best-in-Class, Sustainability Themed, as well as Impact Investing were the least used by investors. However, in 20112017 an increase in the area of Impact Investing can be observed (of over 500\%).

It should be also emphasized the socially responsible market in the European Union is not homogenous. It is characterized by large diversification between countries in terms of SRI strategies (chart 2).

Among the European Union countries, the ones that are characterized by both lower and higher level of diversification in terms of strategies used by investors can be distinguished. The first group undoubtedly includes Germany in which Exclusions play a dominant role. In 2011-2015, over 90\% of investments were made on the basis of this strategy. In 2017, this share was around $86 \%$.

A similar situation occurs in Spain. In 2009-2015, the share of investments based on Exclusions amounted over 70\%. Whereas, in 2017, it was about 59\%. This was accompanied by a significant increase in the share of investments made on the basis of ESG integration (about 23\%).

The higher level of diversification during the analysed period can be observed in Austria. In 2009, assets were almost equally managed with the use of strategies such as Exclusions, Norms-based Screening, Best-In-Class, as well as Engagement and Voting. In subsequent years, there was an increase in the share of investments based on Exclusions (to 50\% in 2011, and around $65 \%$ in 2013-2017).

A similar direction of changes in socially responsible investing can also be observed in Denmark. In 2009-2015, the value of investments made on the basis of Exclusions and Norms-based Screening was at a similar level of around $35 \%$ of the total value of socially responsible investments. In 2017 there was a significant increase in the share of Exclusions (to around 70\%).

Over the analysed period, significant changes in terms of SRI strategies that are being used by investors, have occurred in France. In 2009, the overwhelming value of assets (95\%) was managed with the use of ESG integration. In subsequent years, a gradual decrease in this share with the simultaneous increase in the importance of investments made on the basis of Norms-based Screening, 
have been observed. In 2015 and 2017, their share was around 65\% and 48\%. It should be also noted the low interest in investing on the basis of Exclusions.

Also in Great Britain, exclusions those companies whose activity is disadvantageous from an ethical or social point of view are not the main criterion in the process of socially responsible investing. The share of this strategy in the total value of socially responsible investments ranged from around 5\% in 2009 to around 30\% in 2015-2017. Investors from Great Britain most often base their investment decisions on Engagement and Voting, with a fairly large share of ESG integration.

When analysing individual SRI markets in the European Union, a small change over time can be observed in the Netherlands. Investors made decisions mainly on the basis of strategies such as Exclusions, Norms-based Screening, ESG integration, as well as Engagement and Voting. The relatively similar share of investing with the use of these strategies in particular years should be also emphasized.

A different situation can be observed in Poland. The short history of socially responsible investing causes a need to develop a uniform nationwide criteria for selection of companies to an investment portfolio. They are currently based on investors' individual preferences regarding investments strategy. This is reflected in high level of diversification in terms of strategies used by investors. In 2009-2011 almost all SRI investments were made on the basis of Exclusions (over 95\%). In subsequent years, there was a significant diversification of implemented investments strategies, of which Norms-based Screening played an important role. It should also be noted that in 2015 investors were interested in investing with the use of strategies such as Best-In-Class and Sustainability Themed. While in 2017, there was a complete lack of interest in these strategies with the simultaneous interest in investing on the basis of Engagement and Voting and ESG integration.

\subsection{The reasons for territorial diversification of socially responsible investments in the European Union's capital markets}

The SRI market in the European Union is heterogeneous. It is characterized by diversification in both the value of investments realised and strategies on which they are based. Therefore, it is important to identify the causes of differences in both the level of socially responsible investing, as well as strategies that are being used by investors in individual EU countries.

The reason for this diversification can be found in efficiency factors related to searching an opportunity to increase the efficiency of the investments, measured by profitability and risk associated with investing. However, the research focusing on the efficiency of socially responsible investing in compare to the efficiency of traditional investing do not give a defined answer. They indicate higher efficiency of socially responsible investments (Derwall et al., 2005, pp. 51-63; Statman, 2006, pp. 100-109), no significant differences between 
these form of investments (Statman, 2000, pp. 30-39), as well as the inefficiency of socially responsible investments (Brammer et al., 2006, pp. 97-116). The divergent conclusions from the research cause that searching the reasons for a different level of socially responsible investments in European Union countries only in the area of efficiency of investments, is insufficient. An important role is also contributed to legal and social determinants (Richardson, 2008, p. 7; Williams, 2007, pp. 43-57). The first ones relate to legislative solutions existing in a given country, which create favourable conditions for development of socially responsible investing. Whereas the social determinants refer to the social and environmental awareness of investors.

The level of implementation of legislative solutions undoubtedly has a significant impact on diversity in the level of socially responsible investing in the individual capital markets within the EU. These regulations may oblige investors to incorporate social and environmental issues into investment analysis and decision making processes and to disclose information on the performance of fulfilment of these obligations. They can also require the companies concerned by the investments, to include and communicate on social and environmental aspects. An important role in stimulating development of socially responsible investing can also be fulfilled by fiscal solutions that encourage investors to take into account criteria of corporate social responsibility in the process of creating an investment portfolio (Richardson, 2009, pp. 558-560).

The impact of these regulations is reflected in the functioning of the two largest and most mature SRI markets. In 2001, in France, legal regulations obliging listed companies disclose information regarding their social and environmental impacts, were introduced. The regulations requiring the asset management companies to describe how they take into account ESG criteria in their investment policies were also imposed (Eurosif, 2018, p. 91). An important role in development of socially responsible investing in France was also played by obligation to incorporate by companies at least one socially responsible investing fund into their Employee Savings Scheme, and also by require three major French public institutional investors take into account ESG criteria in their investments (EFAMA, 2016, p. 42).

The other country is Great Britain. The regulations requiring the pension funds to disclose their policies in the field of socially responsible investing have already appeared there in 1999. The introduction of the regulations encouraging socially responsible investing should be also emphasized. These include such as tax relief available to investors who invest in accredited institutions fulfilling specific social functions (Gov.uk, 2019) and tax relief available for individual investors making investments in social enterprises dealing with activities for disadvantaged communities and supporting companies operating in these communities (Gov.uk, 2016).

By contrast, Poland is an example of a country which is in the initial stage of development of socially responsible investing. As of today, there are no legal regulations concerning socially responsible investing, as well as no fiscal solu- 
tions that would encourage investors to take into account the criteria of corporate social responsibility.

\section{Conclusion}

The research focuses only on selected areas of socially responsible investing, however, it is important due to its cognitive aspects. It shows that socially responsible investing, referring to create an investment portfolio on the basis of both traditional financial criteria and key aspects of corporate social performance, plays an increasingly important role in the European Union's capital markets. In relation to the research questions posed, it also allows concluding that:

1. The SRI markets in individual European Union's countries are diversified and develop at a different pace. The largest value of the SRI market among European Union countries is characteristic for the capital markets of France, Great Britain, Germany and the Netherlands. It should be also emphasised that although the value of socially responsible investments in Poland differs significantly from the best results in this field in the European Union, Poland is the only country in Central and Eastern European that are covered by a statistic on socially responsible investing.

2. Investors in the European Union's capital markets base their decisions mainly on four strategies i.e. Exclusions, Engagement and Voting, ESG integration, and Norms-based screening. However, the individual markets are characterized by diversity of preferences regarding investments strategies. Among the European Union countries, the ones that are characterized by both lower and higher level of diversification in terms of strategies used by investors can be distinguished. The first group includes countries such as Germany and Spain, The second group comprises the Member States like Poland and Austria.

3. The level of implementation of specific legislative solutions creating favourable conditions for the development of socially responsible investing has a significant impact on diversity in the level of this type of investing in the individual capital markets within the European Union. The impact of these regulations is reflected in the functioning of the two largest and most mature SRI markets, namely France and Great Britain. For comparison, in Poland which is an example of a country in the initial stage of development of the SRI market, none of this type of regulations has yet been developed.

4. It is necessary to undertake the activities in the institutional and organizational sphere for increasing the level of socially responsible investing in the European Union's capital markets. This requires the use of systemic solutions that allow accurate identification of social and law barriers to the development of the SRI market, and create instruments to overcome these barriers. Such instruments include: 
- undertaking effective actions to promote CSR; which is important due to the fact that an insufficient knowledge in this field is a barrier to the development of socially responsible investing;

- promotion of transparency and credibility of ESG data and principles for socially responsible investing;

- developing guidelines for financial institutions in terms of a broader consideration of ESG risk in investments strategies;

- training for investment advisors in the field of socially responsible investing;

- developing a tool for investors to an evaluation of socially responsible investing;

- strengthening cooperation for socially responsible investing, within SRI funds operating in Europe;

- introducing legal regulations concerning fiscal solutions that would encourage investors to take into account the criteria of corporate social responsibility in the process of creating an investment portfolio.

\section{References}

Bednarowska, Z. (2015). Desk research: wykorzystanie potencjału danych zastanych w prowadzeniu badań marketingowych i społecznych. Marketing i Rynek, 7.

Brammer, S., Brooks, C., \& Pavelin, S. (2006). Corporate social performance and stock returns: UK evidence from disaggregate measures. Financial Management, 35(3). doi:10.1111/j.1755-053X.2006.tb00149.x.

Brest, P., \& Born, K. (2013). When can impact investing create real impact. Stanford Social Innovation, 11(4).

Derwall, J., Guenster, N., Bauer, R., \& Koedijk, K. (2005). The eco-efficiency premium puzzle. Financial Analysts Journal, 61(2). doi:10.2469/faj.v61. n2.2716.

EFAMA. (2016). Report on responsible investments. Retrieved 19.03.2019 from https: / /www.efama.org.

European Commission. (2010). Communication from the Commission: Europe 2020: a strategy for smart, sustainable and inclusive growth (COM/2010/2020).

European Parliament resolution of 6 February 2013 on corporate social responsibility: accountable, transparent and responsible business behaviour and sustainable growth (OJ C 24, 22.1.2016).

Eurosif. (2010). European SRI study 2010. Retrieved 05.01.2019 from http:// www.eurosif.org.

Eurosif. (2012). European SRI study 2012. Retrieved 05.01.2019 from http:// www.eurosif.org.

Eurosif. (2014). European SRI study 2014. Retrieved 05.01.2019 from http:// www.eurosif.org.

Eurosif. (2016). European SRI study 2016. Retrieved 05.01.2019 from http:// www.eurosif.org. 
Eurosif. (2018). European SRI study 2018. Retrieved 05.01.2019 from http:// www.eurosif.org.

Fung, H., Law, S.A., \& Yau, J. (2010). Socially responsible investments in a global environment. Cheltenham-Northampton: Edward Elgar.

Gov.uk. (2016). Social investment tax relief. Retrieved 19.03.2019 from https:// www.gov.uk.

Gov.uk. (2019). Community investment tax relief. Retrieved 19.03.2019 from https://www.gov.uk.

GSIA. (2012). Global sustainable investment review 2012. Retrieved 05.01.2019 from http://gsiareview2012.gsi-alliance.org.

GSIA. (2014). Global sustainable investment review 2014. Retrieved 05.01.2019 from http://www.gsi-alliance.org.

GSIA. (2016). Global sustainable investment review 2016. Retrieved 05.01.2019 from http://www.gsi-alliance.org.

Hofferth, S.L. (2005). Secondary data analysis in family research. Journal of Marriage and Family, 67(4). doi:10.1111/j.1741-3737.2005.00182.x.

Iraya, C., \& Musyoki, L.N. (2013). Performance of socially screened portfolio at the Nairobi Securities Exchange. International Journal of Humanities and Social Science, 3(6).

Kreibohm, E.M. (2016). The performance of socially responsible investment funds in Europe: an empirical analysis. Lohmar: Eul Verlag.

Nielsen, O. (2014). Responsible investments in the Swedish pension fund system: a case study of institutional investors. Uppsala: Uppsala University.

Renneboog, L., Ter Horst, J., \& Zhang, C. (2010). Socially responsible investments funds. In G. Aras, \& D. Crowther (Eds.), A handbook of corporate governance and social responsibility. Farnham: Gower Publishing.

Richardson, B.J. (2008). Socially responsible investment law: regulating the unseen polluters. New York: Oxford University Press.

Richardson, B.J. (2009). Keeping ethical investment ethical: regulatory issues for investing for sustainability. Journal of Business Ethics, 87(4). doi:10.1007/ s10551-008-9958-y.

Schueth, S. (2003). Socially responsible investing in the United States. Journal of Business Ethics, 43(3). doi:10.1023/A:1022981828869.

Sethi, S.P. (2005). Investing in socially responsible companies is a must for public pension funds: because there is no better alternative. Journal of Business Ethics, 56(2). doi:10.1007/s10551-004-5455-0.

Sparkes, R. (2002). Socially responsible investment: a global revolution. Chichester: John Wiley \& Sons.

Statman, M. (2000). Socially responsible mutual funds. Financial Analysts Journal, 56(3). doi:10.2469/faj.v56.n3.2358.

Statman, M. (2006). Socially responsible indexes: composition, performance and tracking error. Journal of Portfolio Management, 32(3). doi:10.3905/ jpm.2006.628411. 
Urwin, R., \& Woods, C. (2009). Sustainable investment principles: models for institutional investors. Retrieved 18.01.2019 from http://uksif.org.

US SIF Foundation. (2016). Report on US sustainable, responsible and impact investing trends 2016. Retrieved 05.01.2019 from https://www.ussif.org.

Wagemans, F.A.J., van Koppen, C.S.A., \& Mol, A.P.J. (2013). The effectiveness of socially responsible investment: a review. Journal of Integrative Environmental Sciences, 10(3-4). doi:10.1080/1943815X.2013.844169.

Waring, P, Burgess, J., \& Lewer, J. (2008). Does socially responsible investment influence employment relations. In S. Marshall, R. Mitchel, \& I. Ramsey (Eds.), Varieties of capitalism, corporate governance and employment systems. Carlton: Melbourne University Press.

Waring, P., \& Edwards, T. (2008). Socially responsible investment: explaining its uneven development and human resource management consequences. Corporate Governance: An International Review, 16(3). doi:10.1111/j.1467-8683.2008.00676.x.

Williams, G. (2007). Some determinants of the socially responsible investment decision: a cross-country study. Journal of Behavioral Finance, 8(1). doi:10.1080/15427560709337016.

World Economic Forum. (2005). Mainstream responsible investment. Retrieved 05.01.2019 from https://community-wealth.org.

\section{Acknowledgements}

Author contributions: authors have given an approval to the final version of the article. Authors contributed to this work equally.

Funding: this research was funded by the University of Bialystok statutory sources.

Note: the results of this study were presented at 10th International Conference on Applied Economics Contemporary Issues in Economy (June 27-28, 2019, Torun, Poland). 


\section{Appendix}

Table 1.

Socially responsible investments by region between 2012 and 2016

\begin{tabular}{lccccrc}
\hline \multirow{2}{*}{ Region } & \multicolumn{2}{c}{2012} & \multicolumn{2}{c}{2014} & \multicolumn{2}{c}{2016} \\
\cline { 2 - 7 } & in USD trillion & in \% & in USD trillion & in \% & in USD trillion & in \% \\
\hline Europe & 8.76 & 66.00 & 10.78 & 59.00 & 12.04 & 52.60 \\
United States & 3.74 & 28.20 & 6.57 & 36.00 & 8.72 & 38.10 \\
Canada & 0.59 & 4.40 & 0.73 & 4.00 & 1.09 & 4.70 \\
Australia/New Zealand & 0.13 & 1.10 & 0.15 & 0.80 & 0.52 & 2.30 \\
Asia & 0.04 & 0.30 & 0.05 & 0.20 & 0.53 & 2.30 \\
\hline total & 13.26 & 100.00 & 18.28 & 100.00 & 22.89 & 100.00 \\
\hline
\end{tabular}

Source: Own preparation based on GSIA (2012, pp. 9-10; 2014, pp. 7-8; 2016, pp. 7-8).

Table 2.

Socially responsible investments in European Union countries between 2009 and 2015

\begin{tabular}{lrrrrrrrr}
\hline \multirow{2}{*}{ Country } & \multicolumn{3}{c}{2009} & \multicolumn{3}{c}{2011} & \multicolumn{2}{c}{2013} \\
\cline { 2 - 8 } & in EUR billion & in \% & in EUR billion & in \% & in EUR billion & in \% & in EUR billion & in \% \\
\hline Austria & 2.10 & 0.05 & 8.30 & 0.15 & 27.00 & 0.36 & 52.20 & 0.55 \\
Belgium & 193.70 & 4.42 & 96.90 & 1.69 & 226.00 & 3.00 & 315.90 & 3.32 \\
Denmark & 242.20 & 5.53 & 244.20 & 4.25 & - & - & 118.40 & 1.24 \\
Finland & 89.40 & 2.05 & 107.60 & 1.88 & 131.50 & 1.75 & 68.00 & 0.71 \\
France & 1850.70 & 42.27 & 1884.00 & 32.78 & 1728.90 & 22.99 & 3121.10 & 32.79 \\
Spain & 33.30 & 0.76 & 57.10 & 0.99 & 93.20 & 1.24 & 95.30 & 1.00 \\
Netherlands & 396.00 & 9.04 & 666.20 & 11.59 & 1244.60 & 16.54 & 991.40 & 10.43 \\
Germany & 12.90 & 0.29 & 621.00 & 10.80 & 897.90 & 11.93 & 1786.40 & 18.77 \\
Poland & 1.10 & 0.03 & 1.20 & 0.02 & 1.10 & 0.01 & 6.00 & 0.06 \\
Sweden & 305.50 & 6.98 & 378.30 & 6.58 & 649.00 & 8.63 & 791.70 & 8.32 \\
Great Britain & 938.90 & 21.44 & 1235.00 & 21.49 & 1973.10 & 26.22 & 1555.30 & 16.34 \\
Italy & 312.40 & 7.14 & 447.60 & 7.78 & 551.90 & 7.33 & 616.20 & 6.47 \\
\hline
\end{tabular}

Notes:

The analysis included the European Union countries, for which data of at least three years, were available. The table 2 does not include data for 2017 due to the lack of data comparability with previous periods. This data present only a total value of each strategy per country. Due to the fact that investors can use more than one strategy in their investment process, aggregation of these data would lead to an overestimation of the real value of investments made in the individual SRI markets within the EU.

Source: Own preparation based on Eurosif (2010, pp. 11-58; 2012, p. 63; 2014, p. 21; 2016, p. 57). 


\section{Chart 1.}

The value of socially responsible investments by strategies in the European Union countries between 2009-2017 (in EUR billion)

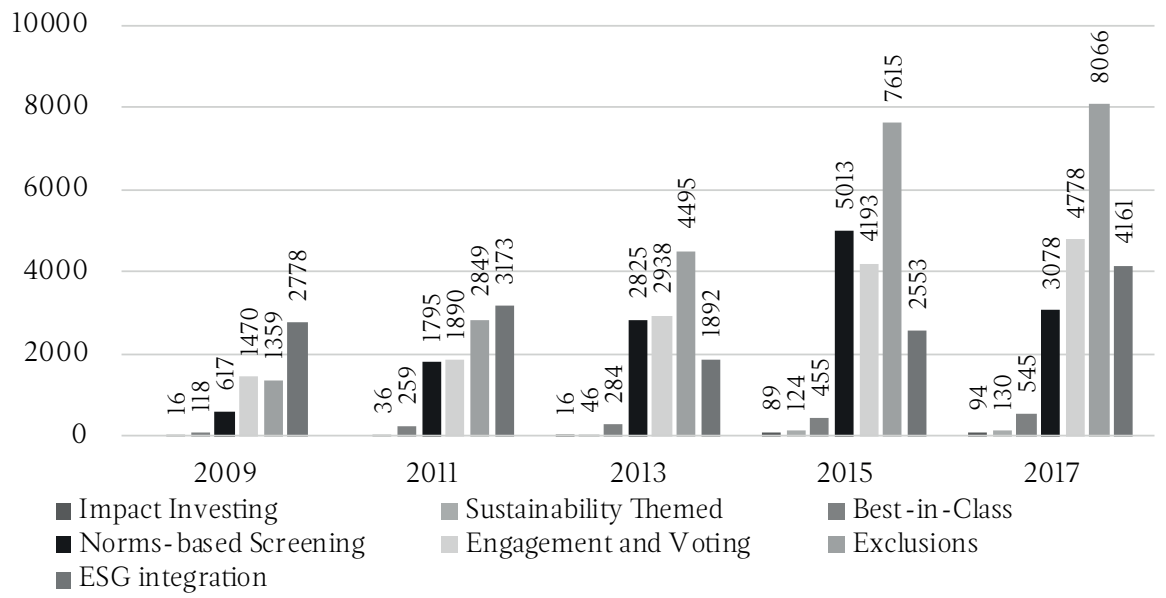

Source: Own preparation based on Eurosif (2010, pp. 11-58; 2012, p. 63; 2014, p. 21; 2016, p. 57; 2018, p. 83). 


\section{Chart 2.}

Socially responsible investing strategies in individual European Union countries between 2009 and 2017 (in \%)

100

80

60

40

20

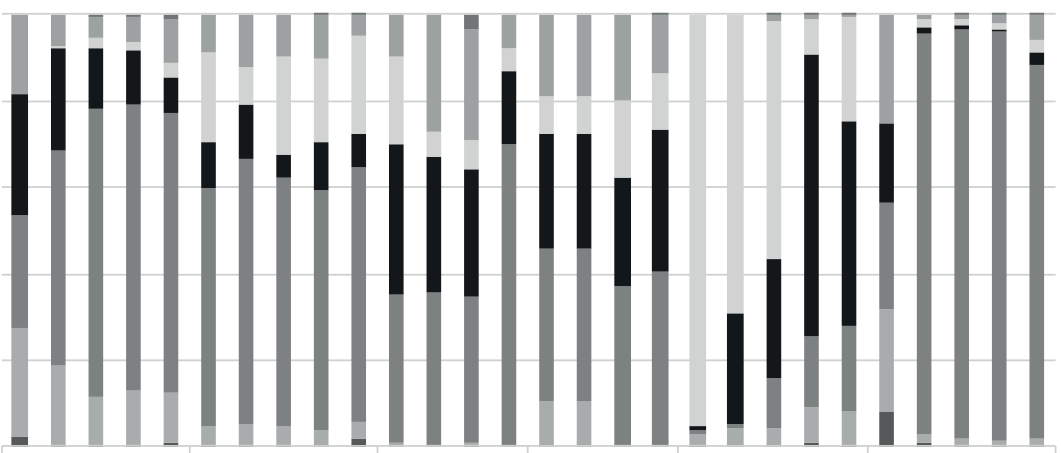

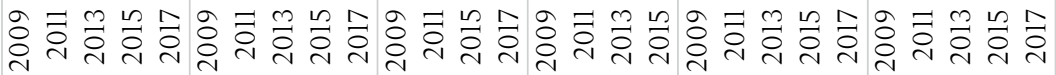

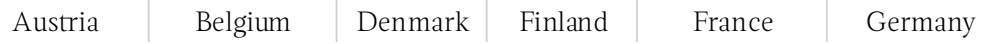

100

80

60

40

20

0

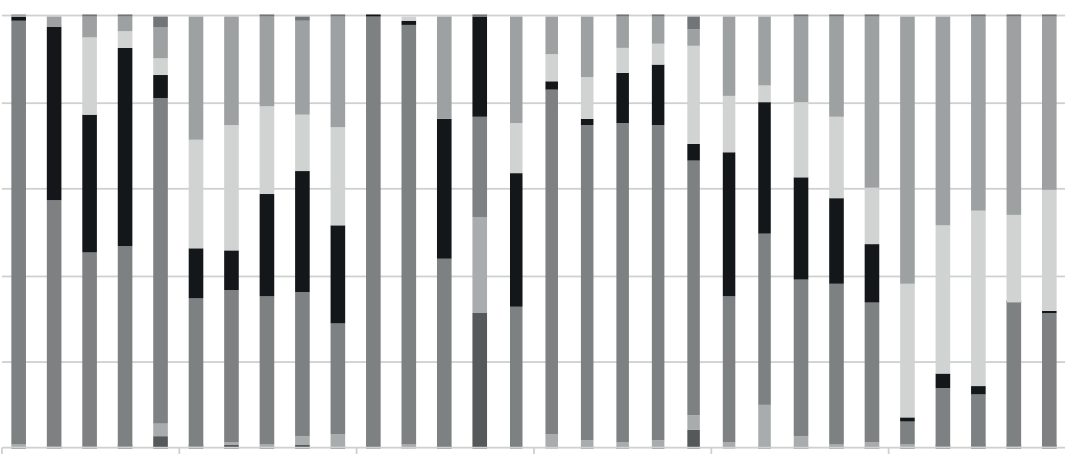

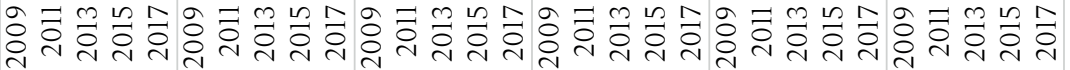

Italy Netherlands Poland

- Sustainability Themed Best-in-Class

- Norms-based Screening ESG integration

- Impact investing
Spain

Sweden

Great Britain

Engagement and Voting

Source: Own preparation based on Eurosif (2010, pp. 11-58; 2012, p. 63; 2014, p. 21; 2016, p. 57; 2018, p. 83). 